\title{
Isolation and characterization of potential probiotic lactic acid bacteria isolated from cow milk and milk products
}

\author{
Vanniyasingam, $\mathbf{J}^{1}$, Kapilan, $\mathbf{R}^{2}$ and Vasantharuba, $\mathbf{S}^{1}$ \\ 1Department of Agricultural Chemistry, University of Jaffna, Kilinochchi, Sri Lanka \\ ${ }^{2}$ Department of Botany, University of Jaffna, Jaffna, Sri Lanka
}

\begin{abstract}
Probiotics refer to the living microorganisms that exhibit beneficial effect on the health of human by the intestinal microbial balance. Most widely used probiotics are lactic acid bacterial group found in milk and milk products. This study was aimed to characterize the probiotic properties of lactic acid bacterial (LAB) strains isolated from cheddar cheese, yoghurt and cow milk. Bacterial strains naturally grown in milk, cheddar cheese and yoghurt were isolated using De Mann Rogosa Sharpe (MRS) agar medium and incubated at $37^{\circ} \mathrm{C}$ for $48 \mathrm{~h}$ separately under aerobic and anaerobic conditions. There were eight strains grown under aerobic conditions and they were isolated, purified and characterization was done based on the morphological and biochemical analysis such as gram staining, catalase test and motility test. All the eight isolates were either rod or cocci shaped, gram positive, catalase negative, non-motile and non-spore formers. These eight isolated strains were identified as lactic acid bacteria. When screening of the 8 isolates was done to determine their antimicrobial activities against five human pathogenic strains such as E.coli, Klebsiella pneumoniae, Pseudomonas eaeruginosa, Salmonella sp and Staphylococcus aureus, three isolates (M6, C1 and Y1) showed wide spectrum antimicrobial activity. To determine the probiotic properties of these three isolates, different tests such as tolerance to acid, $\mathrm{NaCl}$ and bile, lactose utilization and antibiotic resistance were done. Though all the three isolates showed resistance to stomach $p H$ ( $p H$ 3.0), the strain $C 1$ showed significantly higher tolerance to stomach $\mathrm{pH}$ than the other strains. Though the three isolates grew well in the presence of $\mathrm{NaCl}$ and $0.3 \%$ bile, the isolate $\mathrm{M} 6$ showed significantly higher growth with $\mathrm{NaCl}$ and $0.3 \%$ bile than the others. Even though all the three isolates had the capacity of utilizing lactose, the isolate M6 showed prominent colour change in the lactose utilization test than the other two strains. When antibiotic susceptibility of the isolated LABs were evaluated using four antibiotics such as Ampicillin, Streptomycin, Bacitracin and Gentamycin, the strain M6 showed significantly higher resistance to Ampicillin and Bacitracin but sensitive to Streptomycin and Gentamycin. Other two isolates (C1 and Y1) were sensitive to all the four antibiotics used. Based on the antibiotic sensitivity tests and the analysis of probiotic properties, the isolated strain M6 was confirmed as a potential probiotic lactic acid bacterium. This strain was identified as Lactobacillus plantarum strain CIP 103151 through16S rDNA sequence analysis.
\end{abstract}

Keywords: Cheddar cheese, Lactic acid bacteria, Milk products, Probiotic properties

\section{Introduction}

Probiotics are living microorganisms which are beneficial to health when consumed. Milk and milk products are usually associated with probiotic bacteria, which provide supplements for the beneficial maintenance of the intestinal system (Tambekar and Bhutada, 2010). The main Lactic acid producing bacterial (LAB) groups are gram-positive, catalase negative organisms and they belong to genera Lactobacillus, Bifidobacterium, Lactococcus, Pediococcus and Leuconostoc (Leroy and de Vuyst, 2004). There has been an increasing attention in the use of diverse strains of LAB as probiotics, mainly Lactobacilli and Bifidobacteria that are residents of the commensal bacteria in the
Corresponding author: ranganat@ualberta.ca Received: 09.11.2018 https:/ / orcid.org/0000-0002-7608-1615

Accepted: 13.12.2018 
gut of human showing good therapeutic functions (Lavanya et al., 2011). They can produce antimicrobial substances (e.g.: organic acid, hydrogen peroxide and bacteriocins) which can influence the growth of the possible harmful microorganisms. Enteric bacteria comprised of Salmonella species, Shigella species, Proteus species, Klebsiella species, E. coli, Pseudomonas species, Vibrio cholera and $S$. aureus which are major etiologic agents of enteric infection (Ballal and Shivananda, 2002). Further, probiotics are beneficial in gastrointestinal disturbances, such as diarrhoea, dysentery, typhoid etc (Tambekar and Bhutada, 2010). The antagonistic activity of such bacteria can inhibit a large number of enteric and urinary pathogenic bacteria (Hutt et al., 2006). They cause reduced lactose intolerance alleviation of some diarrhoea, lowered blood cholesterol, increased immune response and prevention of cancer. The selection criteria for probiotic LAB include safety, resistance to acid and bile, adherence to gut epithelial substances. The main in vitro selection criteria for potential probiotic strains are acid and bile resistance activities, indicating the ability of the organism to survive during the passage through the gastrointestinal tract. From good quality cheddar cheese, Lactobacillus plantarum and Lactobacillus casei were isolated (Broome et al., 1990). Lactobacillus plantarum and Lactobacillus rhamnosus were isolated from goat milk (Setyawardani et al., 2011). (Tamberkar and Bhutada, 2010) isolated Lactobacillus acidophilus, Lactobacillus brevis,Lactobacillus plantarum, Lactobacillus bulgaricus, Lactobacillus lactis, Lactobacillus casei and Lactobacillus fermentum from milk samples. Therefore, the objective of the study was to isolate lactic acid bacterial (LAB) strains from cheddar cheese, yoghurt and cow milk and to evaluate the probiotic properties of these strains in order to select the potential probiotic bacterial strain.

\section{Materials and methods}

\subsection{Collection of samples}

Cheddar cheese and yoghurt were obtained from Cargills super market, Jaffna. Cow milk was obtained from Kokuvil milk collection centre. Sampling was done randomly according to the studies done by Hoque (Hoque et al., 2010).

\subsection{Isolation of lactic acid bacteria from milk and milk products}

Lactic acid bacterial strains were isolated from milk, yoghurt and cheddar cheese by weighing $1 \mathrm{~g}$ of the sample and serially diluted with $10 \mathrm{~mL}$ sterile distilled water. After homogenization, $10^{-5}$ serially diluted samples were spread on MRS agar medium. The plates were incubated for 48 $\mathrm{h}$ at $37^{\circ} \mathrm{C}$. The characteristic LAB colonies growing over the incubated plates were picked up carefully and streaked on the MRS agar medium following the repeated technique, for further purification. Colonies were transferred to MRS agar slants and then maintained in the refrigerator at $4^{\circ} \mathrm{C}$ for further study (Pundir et al., 2013)

\subsection{Identification of isolated bacterial cultures}

The isolates were subjected to diverse biochemical and morphological studies such as colony morphology, aerobic and anaerobic growth, Gram staining, catalase test and motility test (Hanging Drop Method), in order to identify the genus of the unknown bacterial strains (C1, M6 and Y1) isolated from cheddar cheese, milk and yoghurt. (Barrow and Feltham, 1993, Theivendrarajah, 1990, Kapilan and Arasaratnam, 2010, Karuppaija et al., 2016).

\subsection{Screening of isolated bacterial cultures for antimicrobial activity}

Well diffusion assay method was used for the detection of antimicrobial activity. Antimicrobial activities of the selected isolates were evaluated against Staphylococcus aureus, Salmonella sp, Escherichia coli, Pseudomonas 
aeruginosa,Klebsiella species. Isolate was grown in a nutritional broth at $37^{\circ} \mathrm{C}$ for 24 $\mathrm{h}$ in the incubator. The isolate was centrifuged at 12,000 rpm for $20 \mathrm{~min}$ and the supernatant of each bacterial isolate was collected in a sterilized test tube and the pellet was discarded. Then it was filtered using $0.45 \mu \mathrm{m}$ membrane filter. A $10^{8} \mathrm{CFU} / \mathrm{mL}(100 \mu \mathrm{L})$ suspension of freshly grown test organisms was mixed with $5 \mathrm{~mL}$ of nutrient soft agar and over layered on nutrient agar. Wells of $10 \mathrm{~mm}$ diameter depth were cut in the nutrient agar plates with the help of sterilized cork-borer. An aliquot of $100 \mu \mathrm{L}$ of culture supernatant of each isolate with antimicrobial potential was poured into each well. The plates were then incubated at $37^{\circ} \mathrm{C}$ for $24 \mathrm{~h}$ and zones of inhibition were measured. The isolates, which showed the strongest antagonisms against a maximum number of respective indicators with wide zones of inhibition, were selected for further studies.

\subsection{Evaluation of probiotic potentials of selected Lactobacillus}

Bacterial cultures showing wide spectrum antimicrobial activity were selected for further determination of probiotic potential as follows

\subsubsection{Tolerance of inhibitory substances}

Probiotic features were evaluated by checking the tolerance of the cultures to varying concentrations of acid, salt and bile salts. Tolerance to the above mentioned inhibitory substances was studied in nutrient broth with the concentration of $10^{8}$ CFU/mL $(100 \mu L)$ (Kapilan, 2015). Growth of lactic acid bacteria was monitored using spectrophotometer (Thermo scientific) at wave length of $620 \mathrm{~nm}$ in different $\mathrm{pH}(1,2$, $3,4,5,6$ and 7), $\mathrm{NaCl}$ concentration $(2,4$, $6,8$ and $10 \%)$, and bile salt concentrations $(0.2,0.3,0.4$ and $0.5 \%)$ at $37{ }^{\circ} \mathrm{C}$ for $24 \mathrm{~h}$.

\subsubsection{Lactose utilization}

Lactose utilization was determined using acid production by selected bacterial cultures and it was detected by observing the change in colour of the medium.
Sterilized fermentation medium ( $10 \mathrm{~g}$ peptone, $\mathrm{NaCl} 15 \mathrm{~g}$, phenol red $0.018 \mathrm{~g}$, lactose $5 \mathrm{~g}$, for $1 \mathrm{~L}$ distilled water and final $\mathrm{pH}$ 7.0) was inoculated with different cultures and incubated at $37^{\circ} \mathrm{C}$ for $48 \mathrm{~h}$.

\subsubsection{Antibiotic susceptibility}

The antibiotic resistance of isolated LAB was assessed using antibiotic discs on nutrient agar plates. A $10^{8} \mathrm{CFU} / \mathrm{mL}$ $(100 \mu \mathrm{L})$ suspension of freshly grown test organisms were mixed with $5 \mathrm{~mL}$ of nutrient soft agar and over layered on nutrient agar. The antibiotic discs were placed on the surface of the agar and the plates were incubated at $37^{\circ} \mathrm{C}$ for $24 \mathrm{~h}$. Resistance was assessed against $10 \mu \mathrm{g}$ of Ampicilln, Gentamycin, Streptomycin and Bacitracin. The zone of inhibition was measured in millimeters.

\subsection{Molecular identification}

Genomic DNA from the bacterial isolate (M6) was done using the DNeasy Extraction Kit (Qiagen, USA) following the protocol provided by the manufacturer with modification (Mohanappriya and Kapilan, 2018). An overnight culture grown in MRS liquid medium was centrifuged at $5000 \times \mathrm{g}$ for $10 \mathrm{~min}$, to harvest the cells. The pellet was washed 3 times in Tris - EDTA buffer (TE buffer). Genomic DNA was extracted from $48 \mathrm{~h}$ grown culture plates by using a DNeasy kit (Qiagen, CA). Amplification of the 16S rRNA genes from the genomic DNA, was amplified by Polymerase Chain Reaction (PCR) using bacterial universal primers (27F-AGAGTTTGATCCTGGCTCAG and 1492R- GGTTACCTTGTTACGACTT). The PCR amplification was done in a Techne TC-412 Thermal Cycler (Bibby Scientific Ltd, UK) in a $50 \mu$ reactions containing $25 \mu \mathrm{l}$ of 2 X PCR Master Mix (NorgenBiotek, Canada), $1.5 \mu$ of template DNA $(0.5 \mu \mathrm{g}), 1 \mu \mathrm{l}$ of both forward and reverse primers $(2.5 \mu \mathrm{M}$ of each) and 21.5 $\mu l$ of nuclease free water in a PCR tube added in that order. PCR reaction was done at an initial denaturation step at $94^{\circ} \mathrm{C}$ for $2 \mathrm{~min}$, followed by 30 cycles at $94^{\circ} \mathrm{C}$ for 
$30 \mathrm{sec}, 52^{\circ} \mathrm{C}$ for $30 \mathrm{sec}$ and $72^{\circ} \mathrm{C}$ for $2 \mathrm{~min}$, and a final extension step at $72^{\circ} \mathrm{C}$ for $5 \mathrm{~min}$. PCR products were separated by electrophoresis on a $1 \%$ agarose TAE gel containing ethidium bromide and visualized by UV transillumination (Fotodyne, USA). Cloning was carried out using the PCR TRAP Cloning System (GenHunter Corporation, USA), using the manufacturer's protocol. Amplicons from total bacterial community DNA were spliced into the PCR TRAP Cloning Vector using the T4 DNA ligase. Competent cells were transformed with the recombinant DNA and inoculated in Luria-Bertani (LB)Tetracyclineagar (containing $20 \mu \mathrm{g} / \mathrm{ml}$ of tetracycline). The products were purified, dried, resuspended in $0.1 \mathrm{mM}$ EDTA, and run on a DNA analyzer (3730 Applied Biosystems) using manufacturer's protocols. The resultant nucleotide sequences were edited by using the Sequencer program with Big Dye Terminator cycle sequencer (Macrogen, USA) and aligned. The regions of the bacterial isolate were compared with the sequences of the GenBank database using the Basic Local Alignment Search Tool (BLAST) search program at the National Centre for Biotech Information (NCBI) in order to identify the bacterial isolate.

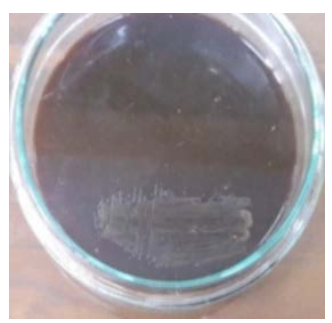

(a)

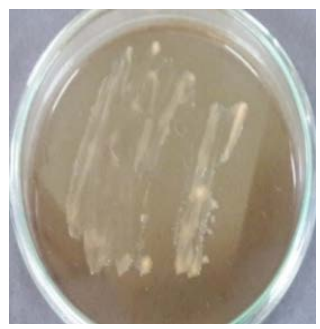

(g)

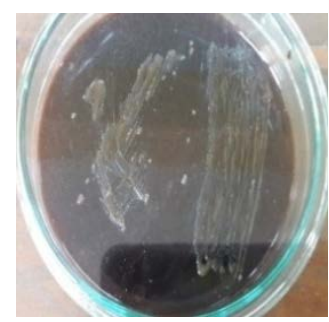

(b)

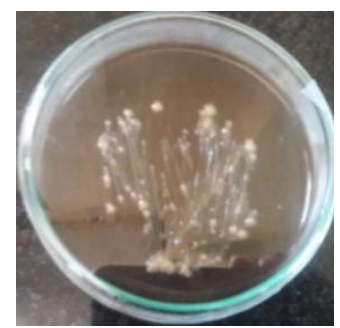

(g)

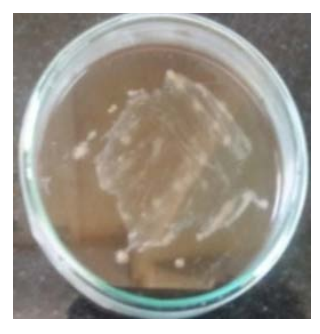

(c)

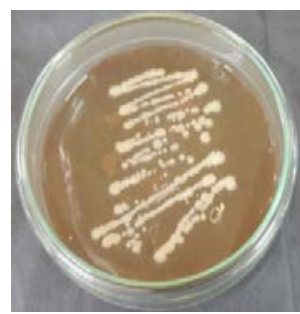

(g)

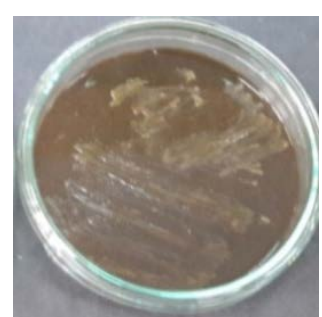

(d)

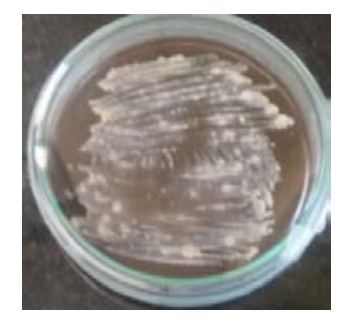

(h)

Plate 1. Isolated Lactic acid bacteria. (a) M1, (b) M2, (c) M3, (d) M4, (e) M5, (f) M6, (g) C1, (h) Y1. Strains M1, M2, M3, M4, M5 and M6 were isolated from milk, strain C1 was isolated from cheddar cheese, and strain Y1 was isolated from voghurt. 


\subsection{Biochemical identification of isolated bacterial cultures}

The main lactic acid producing bacterial (LAB) groups are Gram positive, catalase negative and non-motile organisms (Ananthanarayan et al., 1997, Barrow and Feltham, 1993, Leroy and De Vuyst, 2004). Biochemical characterization of all the isolates were done and their characteristics were noted (Table 1). All the strains were found to be facultative anaerobes, as the strains grown in anaerobic condition and growth also found in presence of oxygen.

All the isolates were found to be grampositive, catalase negative and non-motile. M2, M3, M6, Y1 and C1 were identified as rod shape bacteria. M1, M4 and M5 were identified as cocci shape bacteria. According to the above findings, the isolated strains were identified as lactic acid bacteria.

Table 1. Biochemical characterization of isolates

\begin{tabular}{llllllll}
\hline S.No. & Isolate & $\begin{array}{l}\text { Aerobic } \\
\text { growth }\end{array}$ & $\begin{array}{l}\text { Anaerobic } \\
\text { growth }\end{array}$ & $\begin{array}{c}\text { Gram's } \\
\text { reaction }\end{array}$ & $\begin{array}{c}\text { Catalase } \\
\text { test }\end{array}$ & Shape & Motility \\
\hline 1 & C1 & Positive & Positive & Positive & Negative & Rod & non-motile \\
2 & Y1 & Positive & Positive & Positive & Negative & Rod & non-motile \\
3 & M1 & Positive & Positive & Positive & Negative & Cocci & non-motile \\
4 & M2 & Positive & Positive & Positive & Negative & Rod & non-motile \\
5 & M3 & Positive & Positive & Positive & Negative & Rod & non-motile \\
6 & M4 & Positive & Positive & Positive & Negative & Cocci & non-motile \\
7 & M5 & Positive & Positive & Positive & Negative & Cocci & non-motile \\
8 & M6 & Positive & Positive & Positive & Negative & Rod & non-motile \\
\hline
\end{tabular}

Strain M1, M2, M3, M4, M5 and M6 isolated from milk, strain C1 isolated from cheddar cheese and strain $\mathrm{Y} 1$ isolated from yoghurt.

\subsection{Antimicrobial activity}

Antimicrobial activity is one of the most important selection criteria forprobiotics. Antimicrobial activity tests generally target the enteric undesirables and pathogens (Klaenhammer and Kullen, 1999). Antimicrobial effects of lactic acid bacteria are formed by producing some substances such as organic acids (lactic, acetic, propionic acids), carbon dioxide, hydrogen peroxide, diacetyl, low molecular weight antimicrobial substances and bacteriocins. The results of this study are summarized in Table 2. Eight identified lactic acid bacteria were tested for their antimicrobial activity against selected pathogenic bacteria viz E. coli, Klebsiella pneumoniae, Pseudomonas eaeruginosa, Salmonella sp and Staphylococcus aureus. Antimicrobial activity of different lactic acid bacteria varied against test pathogens. Three isolates (C1, Y1 and M6) showed wide spectrum antimicrobial activity against maximum number of pathogenic organisms. Isolate M1, M3 and M5 were found to inhibit two test indicators respectively whereas; Isolate M2 and M4 were expressed inhibition against one test indicator only. Out of the 8 isolates, M6 isolate showed the maximum zone of inhibition against Pseudomonas eaeruginosa 
followed by E. coli, Klebsiella pneumoniae, Pseudomonas eaeruginosa and C1 isolate exhibited a maximum zone of inhibition against Staphylococcus aureus.

Table 2. Antimicrobial activity of the isolated lactic acid bacteria

\begin{tabular}{|c|c|c|c|c|c|c|}
\hline S.No & Isolate & $\begin{array}{l}\text { E.coli } \\
(\mathrm{mm})\end{array}$ & $\begin{array}{l}\text { Klebsiella } \\
\text { pneumoniae } \\
(\mathrm{mm})\end{array}$ & $\begin{array}{l}\text { Pseudomonase } \\
\text { aeruginosa } \\
(\mathrm{mm})\end{array}$ & $\begin{array}{l}\text { Salmonella } \\
\text { sp } \\
(\mathrm{mm})\end{array}$ & $\begin{array}{l}\text { Staphylococcus } \\
\text { aureus } \\
(\mathrm{mm})\end{array}$ \\
\hline 1 & C1 & $12.92 \pm 0.1$ & $10.9 \pm 0.1$ & $10.86 \pm 0.2$ & NA & $14.92 \pm 0.1$ \\
\hline 2 & Y1 & NA & $11.1 \pm 0.1$ & $12.49 \pm 0.4$ & $11.59 \pm 0.2$ & $13.97 \pm 0.2$ \\
\hline 3 & M1 & NA & $10.55 \pm 0.1$ & NA & $10.78 \pm 0.1$ & NA \\
\hline 4 & M2 & $10.80 \pm 0.2$ & NA & NA & NA & NA \\
\hline 5 & M3 & NA & NA & $10.98 \pm 0.1$ & $11.11 \pm 0.2$ & NA \\
\hline 6 & M4 & NA & $11.36 \pm 0.3$ & NA & NA & NA \\
\hline 7 & M5 & NA & NA & $11.3 \pm 0.1$ & $10.8 \pm 0.1$ & NA \\
\hline 8 & M6 & $12 \pm 0.3$ & NA & $17.51 \pm 0.2$ & $10.96 \pm 0.1$ & $12.55 \pm 0.1$ \\
\hline
\end{tabular}

Clear zones were measured in $\mathrm{mm}$. Results represent the mean \pm standard deviation of three replicates. Strain M1, M2, M3, M4, M5 and M6 isolated from milk, strain C1 isolated from cheddar cheese and strain $\mathrm{Y} 1$ isolated from yoghurt. 'NA' -No activity.

\subsection{Evaluation of the probiotic potential of selected Lactobacillus}

\subsubsection{Tolerance of inhibitory substances}

When evaluating the potential of using lactic acid bacteria as effective probiotics, it is generally considered necessary to evaluate their ability to resist the effects of $\mathrm{pH}$, bile and $\mathrm{NaCl}$. Tolerance to acidic

condition is the most commonly used method to detect the viability and activity of probiotic bacteria in the small intestine and stomach. According to a previous study by (Azat et al, 2016), the survival rate at $\mathrm{pH} 3.0$ is considered as optimal acid tolerance for selected probiotic strains. In present research, isolates M6, C1 and Y1 were assessed for their viabilities in the different $\mathrm{pH}(7,6,5,4,3,2$ and 1$)$ during 24 $h$ of incubation. Based on the Optical
$\mathrm{LAB}$ isolates were able to grow in $\mathrm{pH} 7,6$, $5,4,3$ and 2 but were unable to grow at $\mathrm{pH}$ 1 during 24 hours incubation (Figure 1).All three isoates able to tolerate $\mathrm{pH}$ 3.Therefore, they can be considered as acid tolerance LAB strains and among the three isolates, strain $\mathrm{C} 1$ and $\mathrm{M} 6$ were having better $\mathrm{pH}$ tolerance compared to strain Y1.(Shobharani and Agarwal, 2011) reported that L. paramesenteroides, a potent probiotic strain isolated from cheddar cheese which was found to survive in $\mathrm{pH}$ 4.0 , but no growth was observed with substantially decrease in the $\mathrm{pH}$. The difference in the results may be due to the acid regulatory mechanisms of the $L A B$ have failed to maintain their intracellular $\mathrm{pH}$ and the internal acidification had reduced the activity of enzymes, damaged certain proteins and DNA, which leads to death and different source used for the isolation of Lactobacillus. 
The human liver secretes bile into the small intestine each day, and thus exposure to bile is a serious challenge to probiotics. Therefore, tolerance to bile salt has often been used as the most important selection criteria. The relevant physiological concentration of human bile ranged from $0.3 \%$ to $0.5 \%$ (Dunne et al, 2001). In present study, the survival of isolates at different bile salts concentration $(0.2 \%, 0.3 \%, 0.4 \%$ and $0.5 \%$ ) was examined during 24 hours incubation. All isolates were also bile tolerant and among the three isolates, strain M6 was having better bile tolerance compared to strain $\mathrm{C} 1$ and Y1 (Figure 2). Similar results were obtained by chauhan and daru (2016), in an experiment carried out with 14 Lactobacillus isolated from milk, curd and faecal sample. All 14 Lactobacillus were found to show growth at bile salt $0.3 \%$ concentration. Among these isolates, B.A.2 showed maximum growth at $0.3 \%$ bile concentration and with increase in bile salts concentration, the tolerance level of isolates declined.

$\mathrm{NaCl}$ is an inhibitory substance which may inhibit the growth of certain types of bacteria. If the lactic acid bacteria were sensitive to $\mathrm{NaCl}$ than it would not be able to show its activity in presence of $\mathrm{NaCl}$ so it was essential to test the $\mathrm{NaCl}$ tolerance of lactic acid bacteria. In the present study, the isolates were able to tolerate $2-10 \%$ $\mathrm{NaCl}$ concentration as shown in Figure 3. Among the three isolates, strain M6 showed better tolerance compared to strain $\mathrm{C} 1$ and Y1. Similar results were obtained by Hoqueet al. (2010), in an experiment carried out with Lactobacillus sp. isolated from yoghurts.

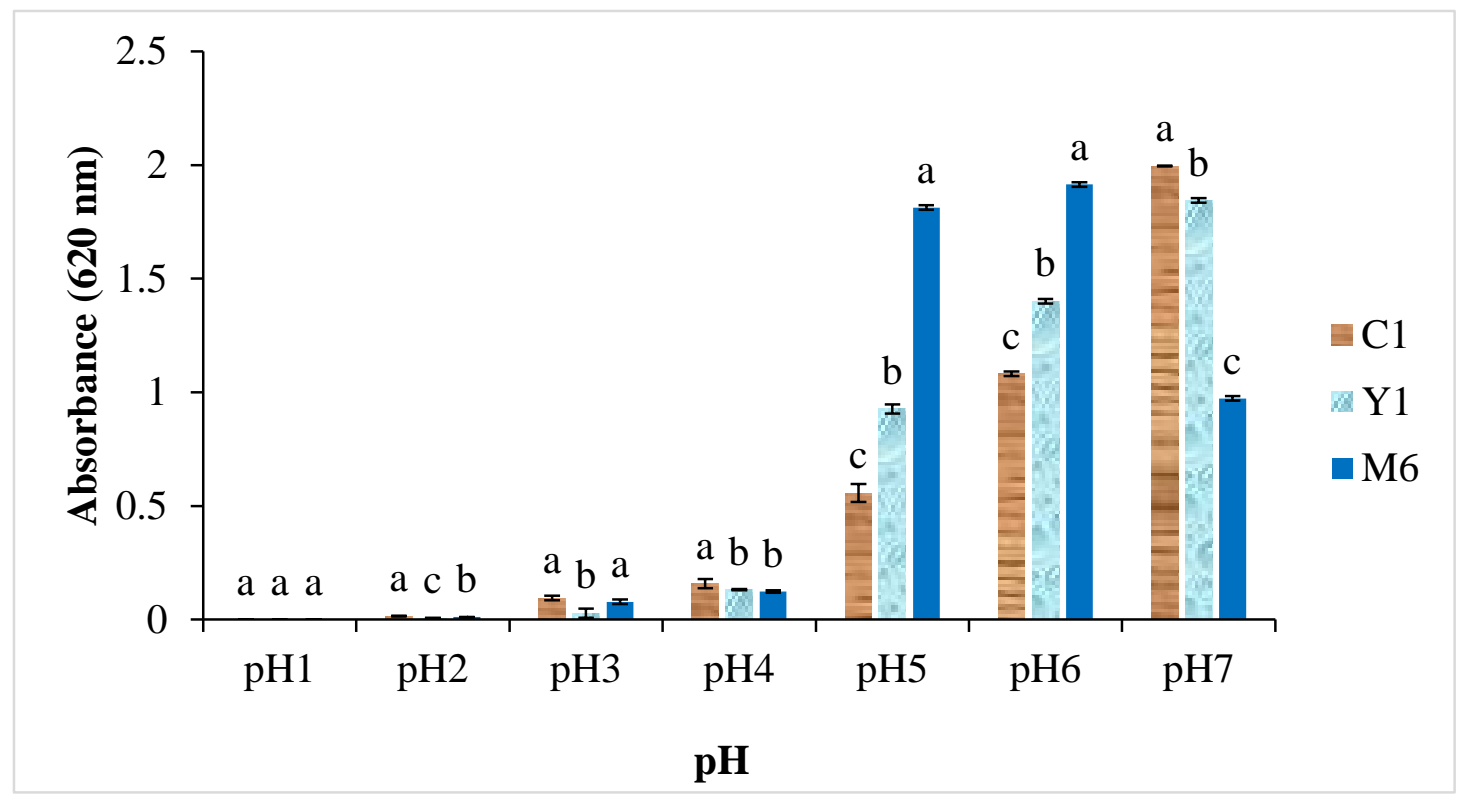

Fig.1. Effect of different $\mathrm{pH}$ on selected Lactobacillus isolates. Means with different letters within the same column indicate significant difference at $\mathrm{p}<0.05$ 


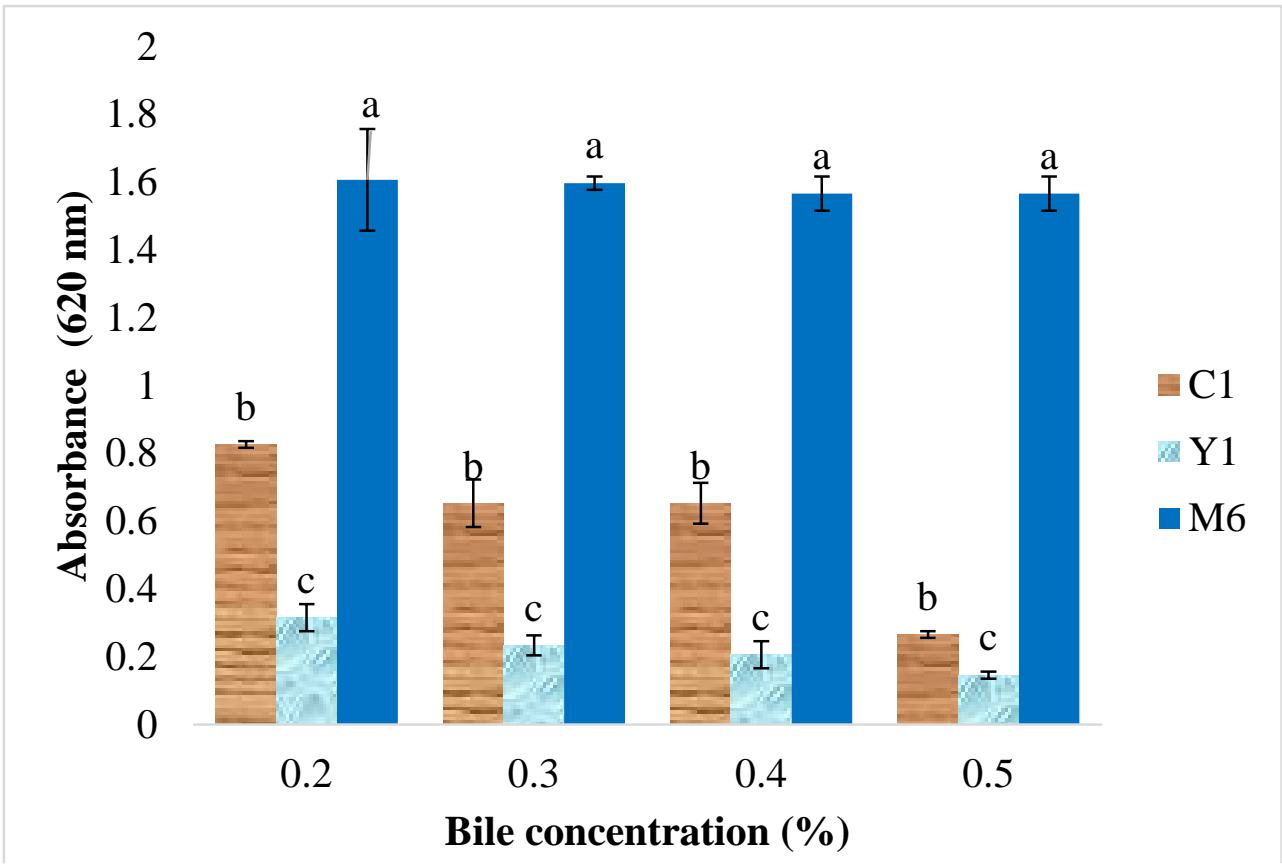

Fig.2. Effect of different concentration of bile on selected Lactobacillus isolates. Means with different letters within the same column indicate significant difference at $\mathrm{p}<0.05$.

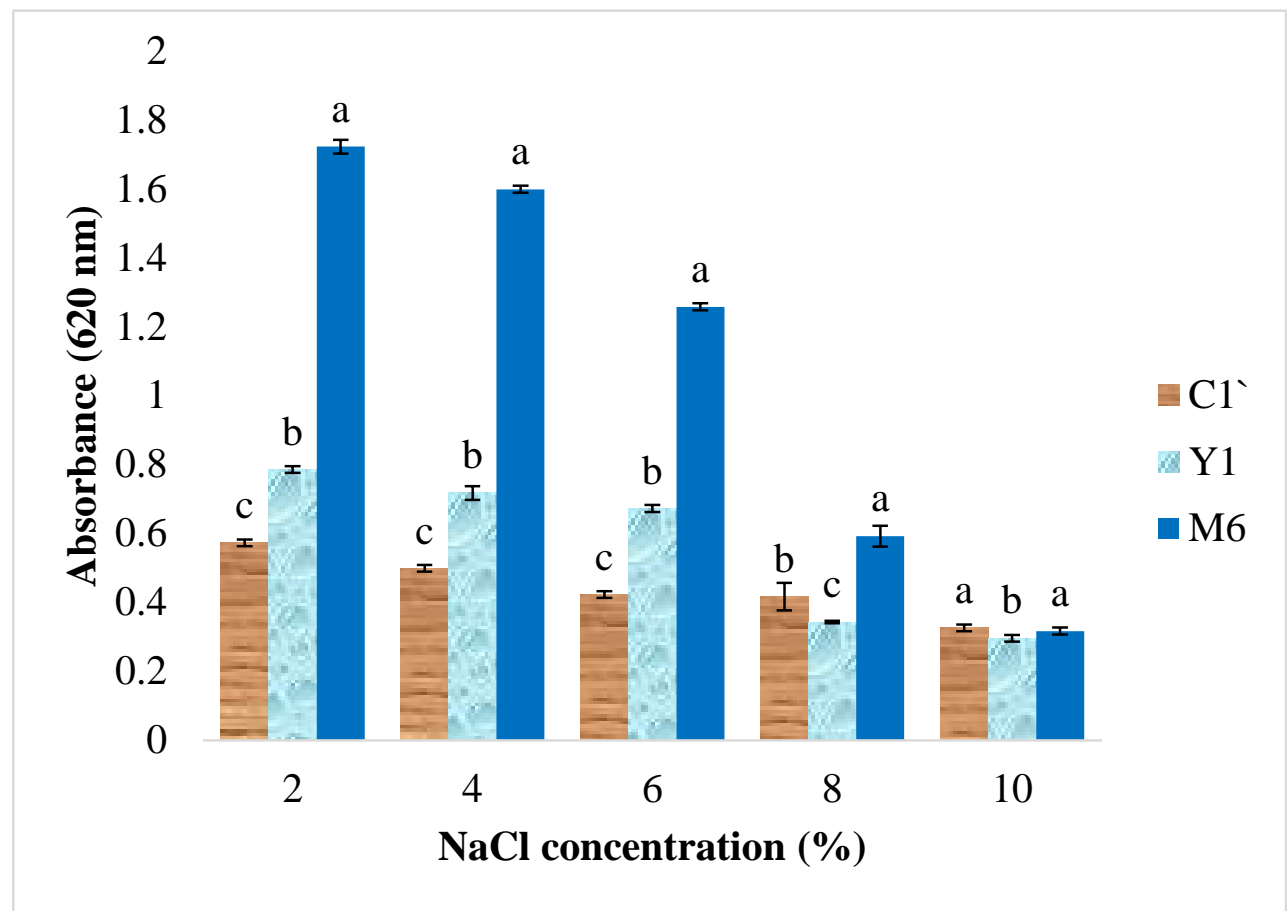

Fig.3 Effect of different concentration of $\mathrm{NaCl}$ on selected Lactobacillus isolates.Means with different letters within the same column indicate significant difference at $\mathrm{p}<0.05$. 


\subsubsection{Lactose utilization}

In the present study the selected LAB isolates (M6,C1 and $\mathrm{Y} 1)$ were grown in nutrient broth medium supplemented with lactose and was observed for change in colour from red to yellow/orange which indicates the production of lactic acid. It was observed that every selected LAB isolate was able to produce lactic acid from lactose. A similar observation was noted by Pundir et al. (2013) with selected LAB products (Fookset al., 1999) isolates using lactose medium. Lactose intolerant people cannot metabolize lactose due to the lack of essential enzyme $\beta$ galactosidase. When they consume milk or lactose-containing products, symptoms including abdominal pain, cramping and diarrhoea arise. The studies provide that the addition of certain starter cultures, allows the lactose intolerant people to consume those

Table 3. Antibiotic sensitivity patterns of the selected Lactobacillus isolates

The diameter of inhibition zones(mm)

$\begin{array}{clccc}\text { Isolates } & \text { Ampicillin } & \text { Streptomycin } & \text { Bacitracin } & \text { Gentamycin } \\ \text { M6 } & \mathrm{R} & 17.56 \pm 0.4 & \mathrm{R} & 18.02 \pm 0.1 \\ \text { C1 } & 42 \pm 0.1 & 12.3 \pm 0.2 & 10.07 \pm 0.1 & 26.04 \pm 0.3 \\ \text { Y1 } & 14.2 \pm 0.2 & 16.05 \pm 0.3 & 11.7 \pm 0.1 & 20.56 \pm 0.2\end{array}$

Inhibition zones were measured in mm. Results represent the mean \pm standard deviation of three replicates. $\mathrm{R}$ - Resistance

\subsubsection{Antibiotic sensitivity test}

Antibiotic susceptibility of lactic acid bacteria is one of the crucial criteria from the safety point of view of potential probiotics. Three potentially probiotic lactic acid bacteria isolates were subjected to antibiotic susceptibility testing using the disc diffusion method (Table 3). The strain M6 was resistant to two antibiotics such as Ampicillin and Bacitracin but sensitive to Streptomycin and Gentamycin. Other two strains (C1 and Y1) were sensitive to all the antibiotics tested (Plate 2). Tambekar and Bhutada (2010)determined the antibiotic sensitivity profile of 11 lactic acid bacteria isolated from milk of domestic animals and commercial available probiotic preparationand most of the stains were resistant to Ampicillin and Gentamycin.Shobharani and Aagarwal (2011) determined the antibiotic sensitivity profile of lactic acid bacteria isolated from cheddar cheese, Leuconostoc paramesenteroides was found to be resistant to Streptomycin and Gentamycin and sensitive to Ampicillin and Bacitracin.The difference in results may be due to different source used for the isolation of lactic acid bacteria and vary from strain to strain or type of strain. 


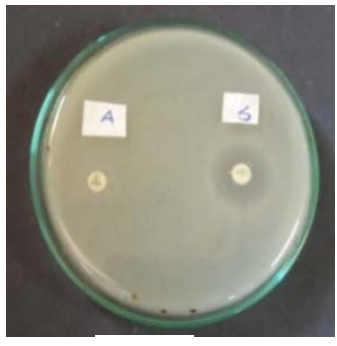

(a)

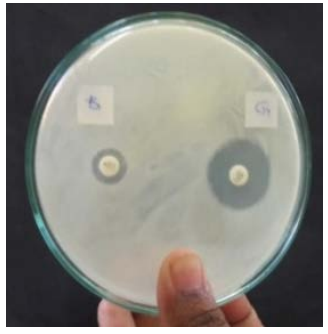

(d)

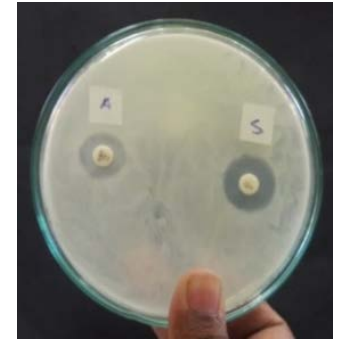

(b)

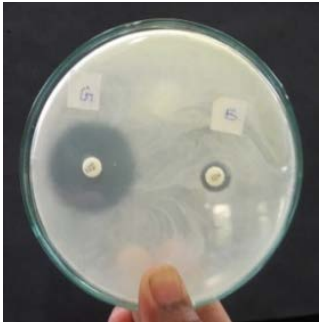

(e)

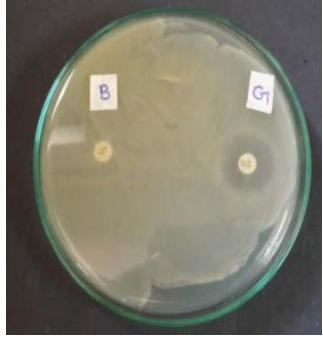

(c)

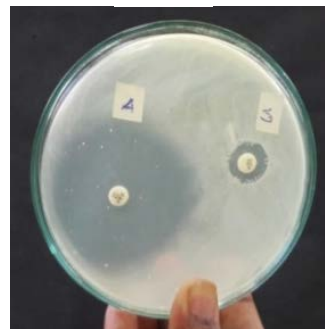

(f)

Plate 2. Resistance and sensitivity of Lactobacillus isolates for different antibiotics (a) Isolate M6 resistance to $A$ and sensitivity to $S(b)$ Isolate $M 6$ resistance to $B$ and sensitivity to $G(c)$ Isolate $\mathrm{Y} 1$ sensitivity to $A$ and $S(d)$ Isolate $Y 1$ sensitivity to $B$ and sensitivity to $G$ (e) Isolate $C 1$ sensitivity to A and sensitivity to $S$ (f) Isolate $C 1$ sensitivity to $G$ and B. A - Ampicillin, B Bacitracin, S - Streptomycin, G - Gentamycin,M6 - LAB isolated from milk, C1 - LAB isolated from cheddar cheese, $\mathrm{Y} 1-\mathrm{LAB}$ isolated from yoghurt.

\subsection{Molecular identification}

Selected lactic acid bacterial isolate (M6) was identified by using the method of analysis of genus specific PCR and 16S rDNA sequence analysis and NCBI BLAST. Total 495 base pairs partial 16S rDNA sequence was retrieved in FASTA format and subjected for BLAST search in GenBank. The query sequence showed 100 $\%$ similarity with the Lactobacillus plantarum in NCBI BLAST suggests the relatedness of the tested organism with same and identity within the genus. The potential probiotic lactic acid bacterium (M6) was identified as Lactobacillus plantarum strain CIP 103151. The similar strain was obtained by Qianet al. (2018), in an experiment performed with the strain isolated from yak yoghurt using the methods of homology analysis of genus specific PCR,16S rDNA sequences and species specific PCR.

\section{Conclusion}

There are eight bacterial strains isolated from cow milk, cheddar cheese and yoghurt. Characterization by biochemical tests and the morphological study confirms that all the isolates are lactic acid bacteria. Three isolates that showed wide spectrum antimicrobial activity against five human pathogens were chosen for the determination of probiotic potential. Based on the probiotic properties, isolate M6 is concluded as promising probiotic bacteria and identified as Lactobacillus plantarum strain CIP 103151 based on the biochemical and $16 \mathrm{~S}$ rDNA sequence analysis.

\section{Acknowledgement}

The authors sincerely express their gratitude to the National Research council and University of Jaffna for the research grants in 2017. 


\section{References}

Ananthanarayan, R. and Paniker, C. K. J. (1997). In: Text Book of Microbiology. Ed. Paniker, C. K. J, Indcom Press, Chennai. 46-49.

Azat, R., Liu, Y., Li, W., Kayir, A., Lin, D., Zhou, W. and Zheng, X. (2016). Probiotic properties of lactic acid bacteria isolated from traditionally fermented Xinjiang cheese, Journal of Zhejiany - SCIENCE B, 17(8):597-609

Ballal, M. and Shivananda, P.G. (2002). Rotavirus andenteric pathogens in infantile diarrhoea in Manipal South India,Indian Journal of Pediatrics, 69:393-396.

Barrow, G. I. and Feltham, R. K. A. (1993). Staining of Bacteria. In: Cowan and Steel's Manual for the identification of medical bacteria. Eds. Barrow, G. I. and Feltham, R. K. A. Cambridge University Press, Great Britain. ISBN 0-521-32611-07. 51-93.

Broome, M.C., Krause, D.A. and Hickney, M.W. (1990). The isolation and characterization of lactobacilli from cheddar cheese, Australian Journal of Dairy Technology, 45:60-66.

Chauhan, B.P., and Daru, D. (2016). Isolation and characterization of lactobacillus from milk, curd and fecal sample and assigning their probiotic values, International Journal of Pharma and Bio Sciences, 7(3):1070 - 1075.

Dunne, C., O'Mahony, L., Murphy, L., Thornton, G., Morrissey, D., O'Halloran, F.M., Flynn, S., Fitzgerald, G., Daly, C., Kiely, B., O'Sullian, G., Shanahan, F. and Collins, J.K. (2001). Invitroselection criteria for probiotic of human origin: correlation with in vivo findings, American Journal of Clinical Nutrition, 73(2): 386-392.

Fooks, L.J., Fuller, R. and Gibson, G.R. (1999). Prebiotics, probiotics and human gut microecology, International Dairy Journal, 9:53-61.
Hutt, P., Shchepetova, J., Loivukene, K., Kullisaar, T. and Mikelsaar, M. (2006) Antagonistic activity of probiotic Lactobacilli andbifidobacteriaagainst enteroand uropathogens, Journal of applied Microbiology, 100:1324-1332.

Hoque, M.Z., Akter, F., Hossain, K.M., Rahman, M.S.M., Billah, M.M. and Islam, K.M.D. (2010). Isolation, identification and analysis of probiotic properties of Lactobacillus spp. from selective regional yoghurts, World Journal of Dairy Food Science, 5(3):9-46

Kapilan, R. (2015). Determination of antibacterial activity of some important spices, International Journal of Research Granthaalayah, 3(10):57-64.

Kapilan, R.and Arasaratnam, V. (2010). A Novel Bacillus pumilus strain for alkaline xylanase production at and above $40^{\circ} \mathrm{C}$. Ceylon Journal of Science (Bio Science), 39(1):61-70.

Karuppaija, S. Kapilan, R and Vasantharuba, S. (2016). Characterization of best naringinase producing fungus strain isolated from palmyrah (Borrasusflabellifer) fruit pulp, International Journal of Biological Research, 4(2):97-101.

Klaenhammer, T.R., Kullen, M.J. (1999) Selection and design of probiotics, International journal of food microbiology, 50: 45-57.

Lavanya, B., Sowmiya, S., Balaji, S. and Muthuvelan, B. (2011). Screening and characterization of lactic acid bacteria from fermented milk, British Journal of Dairy Sciences, 2(1): 5-10.

Leroy, F. and De Vuyst, L. (2004). Lactic acid bacteria as functional starter cultures for the food fermentation industry, Trend in Food Science \& Technology, 15(2): 67-78. 
Mohanappriya, S. and Kapilan, R. (2018). Isolation of efficient cellulase producing Aspergillus unguis UCSC324 and determination of the kinetic properties of the crude cellulase, Agrieast, Journal of Agricultural science, 12(2):35-48

Pundir, K.R., Rana, S., Kashyap, N. and Kaur, A. (2013). Probiotic potential of lactic acid bacteria isolated from food samples: an in vitro study, Journal of Applied Pharmaceutical Science, 3(3):085-093

Qian, Y., Long, X., Pan, Y., Li, G. And Zhao, $X$. (2018). Isolation and identification of lactic acid bacteria (Lactobacillus plantarum YS2) from yak yoghurt and its probiotic properties, Biomedical research, 29(4): 815820

Setyawardani, T., Rahayu, W.P., Maheswari, R. And Palupi N.H.S. (2011). Identification and Characterization of Probiotic Lactic Acid Bacteria Isolated from Indigenous Goat Milk, Animal Production, 13(1):57-63

Shobharani, P. and Aagrawal, R. (2011). A potent probiotic strain from cheddar cheese,Indian Journal of Microbiology, 51(3):251-258
Sieladie, D.V., Zambou, N.F., Kaktcham, P.M., Cresci, A. and Fonteh, F. (2011). Probiotic properties of Lactobacilli strains isolated from raw cow milk in the Western Highlands of Cameroon, Innovative Romanian Food Biotechnology, 9:12-28.

Shobharani, P. and Aagrawal, R. (2011). A potent probiotic strain from cheddar cheese, Indian Journal of Microbiology, 51(3):251-258.

Tambekar, D.H. and Bhutada, S.A. (2010). An evaluation of probiotic potential of Lactobacillussp. from milk of domestic animals and commercial available probiotic preparations inprevention of enteric bacterial infections. Recent Research in Science and Technology,2(10): 82-88.

Theivendrarajah, K. (1990). Microbiology Laboratory Manual: Department of Botany, University of Jaffna. University Publication. 1-33. 